Advances in Social Science, Education and Humanities Research (ASSEHR), volume 81

1st International Conference on Social and Political Development (ICOSOP 2016)

\title{
Analysis of Community-Based Waste Management in Medan
}

\author{
Hatta Ridho, Muhammad Arifin Nasution
}

\author{
Faculty of Political Studies of University of Sumatera Utara, Medan \\ email: hattaridhofisipusu@gmail.com
}

\begin{abstract}
Waste as products arising from human activities each time, garbage in certain circumstances be a problem for humans.This study aims to investigate the waste management policy and obstacles encountered in Medan as well as providing an alternative model of community-based waste management that are relevant for the city of Medan.This research was conducted with the combination approach through the incorporation of qualitative and quantitative approaches to the dominant model of dominant-less design.Data were analyzed using descriptive-analytic method.The research findings showed the limitations of facilities and infrastructure Medan city government to manage waste so that community involvement be an alternative solution in resolving the garbage problem in the city of Medan.
\end{abstract}

Keywords: Waste Management, Society, City of Medan.

\section{INTRODUCTION}

Garbage basically produced by man due to the presence of human activities .Every human activity must make exiles or junk number and his volume comparable to the level of consumption of us up to goods or material that we use daily.Similarly with garbage, depends on lifestyle and the material that we consumption .The phenomenon of this matter has become matter every local governments in Indonesia and the alternative solution with the community development in garbage management. Study of Berampu \& Agusta (2015:127) found that society participation in management of garbage program can mount because several things among others can improve economic opportunity of society. In most society coat have potency to be cared by support of woman clan as study of Ankesa et.al ( 2016) showing woman group participation height which is have status to as housewife in handling of waste.

Waste not be an important issue for developing countries but also garbage into issues is in developed countries to solve especially industrialized nations producing trash in the form of hazardous waste as described in articles Ahn, J \& Suzuki, A ( 1990:
89-94 ) on international conference in Japan on the topic of radioactive waste management in 1989.

Based on the calculation on as outlined in the Indonesia infrastructure (Bappenas, 2003), in 1995 estimates pileup trash in Indonesia reach 22.5 million tons, and increased more than double by the year 2020 be 53,7 million tons.While in big cities in Indonesia it is estimated that garbage per capita ranged from 600-830 grams a day.As an illustration how much garbage produced, data several big cities in Indonesia can be the reference.Jakarta every day produce garbage of 6.2 thousand tons, Bandung city of 2.1 thousand tons, throughout Surabaya 1.7 thousand tons, and Makassar get 0.8 thousand tonnes (Damanhuri, 2002).The number of will have effort that is slightly in handling

The complexity waste management the increases in the town, in this case centralization economic activities and the extent of urban areas .Centralization is going to improve economic activity and the extent of the city. Centralization is going to improve economic activity, which attracts newcomers more and increasing the number of town, so city will face the problem volume and garbage increasing. The development of cities that 
extends shall draw a challenge for the city in implementing services afford all the settlement effectively and efficiently.

This dump activities can create multiplier effect through of the use of ttg. Community to begin to aroused to create a variety of technologies supporting waste management, starting from technology places dump in a household to be used as fertilizer compost, technology of the waste to be a who economically valuable and marketing the waste management.

The main problems is awareness to manage garbage into something useful or at least manage garbage in order to ease environmental implemented in life in communities. The waste problem is considered as problems the government, this needs to be gain the activities and program capable of enable people in manage waste.

For households and companies the waste problem is a job that is not endless to think about this problem the of the city of Medan own with a population of 2.109.339 (Census 2011 ), every day the amount of trash who produced by the no less than 1.543 tons, with the amount of trash this much so often make a conflict in society.In reduced space conflict and to overcome the problem of waste, then the city government Medan through the office of sanitation provide 64 new locations as temporary shelters (in bahasa called TPS)cross over 3 operational areas management and two locations final disposal place (TPA) with broad each TPA $176.392 \mathrm{~m}^{2}$ for a Namo Bintang Pancur Batu sub-district and $137.563 \mathrm{~m}^{2}$ TPA Terjun in sub-district Medan Marelan, assisted by by 104 units of trash transport and 1.741 soul of the number of workers (Statistic center agency of Medan, 2015).

The method applied in the management of the city cleansing Medan is the application of waste management, which includes places, transport and destruction .This method perceived not running because finally most city waste if field reached waste disposal (TPA) only abandoned on the surface and no the use of waste with the technology be an ingredient have resources and to.
In 2015, Medan have implemented waste management by means of $3 \mathrm{R}$, namely reuse, reduce, and recycle community based. This regulation is conducted considering trash production every year increases without accompanied by infrastructure adequate waste.

Waste be a significant issue in trouble an urban environment including housing faced in line with developments in the population and the increase in activity of city develop. Waste not managed well is one reason why the increases in water pollution, the ground and air and improve flood potential waste in city. The problem need to be addressed seriously with technical, operational and proper management and integrated based on conditions and regional policies.

By this conditions on an assessment in the research on analysis of community-based waste management in Medan city in strengthening the implementation of Medan public policy for the future community based effectively.

\section{METHODS}

The research uses design research combination through the merger qualitative and quantitative approaches with a model dominant-less dominant design. The following considerations why used method of a qualitative approach, for his first, if researchers face by the fact double easy adjusted; second, presenting directly the nature of the relationship between researchers and respondent; third, more sensitive and more can adapt to many sharpening influence together and patterns value a facing (Moelong, 2006; 34). The results of the data collected done by using the method descriptive-analytic.

\section{DATA AND RESULT The Implementaion of Community-Based Waste Management}

Community based approach is recognized as solution alternative effective for various problems faced by the government in managing regions .Greater involvement public participation directly to solve problem can be used to face the is sustainable as waste and that is not expected as a natural disaster 
(Wiwaha, A.A., et.al, 2016: 34-48) for local knowledge that owned by the people can really help solve the problem.

The activities waste management community based in the community Medan city having relevance and strong correlation limited government to provide infrastructure support the activities of waste management. The act of Medan government to reduce trash to be managed and encourage the active involvement of the community, reflect the mindset shift in the body the government about the waste management as well as the awareness on the role of and interaction between the government and the community in it.

One of the breakthroughs large in waste management in Indonesiais Bank of Trash Program.Through this program, people idea of the trash is something useless, converted into something which also has a value and prices. By Bank of Trash, people can save a trash, and in particular time could make money.

The concept of community empowerment includes understanding development community and communitybased development (development which rests on society), and the next stage of community appear term driven development rendered as directed development community development or termed powered the community. The process drew how consistency of the program of empowerment conducted by the government.

Bank of Trash is one alternative invite the citizens concerned with garbage, that the concept may be developed in other areas. Trash bank is a waste management system based households, with the chastisement who give cash grants or coupons free to those who successfully the sorting and paid a number of garbage. Trash bank is a place of collecting lots of trash that has been transversely in accordance with its kind to deposited into place this work environment health or a more familiar called trash bank, the results of the subscription of the garbage will be saved and can be taken or liquefied in times of time on common.
Generally process of waste management with the base community in Medan city through the Bank of Trash consisting of several stage of the proceedings, there is:

1. Keep trash managed, divided and processed an early stage from the garbages itself (in this case the majority are households) environment. This effort at least can reduce garbages to be gathered and transported to the polls and load be reduce.

2. In the earliest phase at the household level at least attempts to cultivate organic waste into compost and inorganic waste be sorted and collected according to its kind so allowing recycle to. TPSnumber need to be increased by placed a men there to assist the management in every household. The results of observations condition TPS in some cities in Indonesia known that each inorganic waste very have economic value.

3. Next phase is trash processing which was not possible to process at every neighborhood households that have TPS. TPS existing by using this approach then converted them into a kind of factory integrated waste processing, that product is results is compost, recycled and not waste that can be processed again.

4. The end was stage transporting the rest of trash, trash can be recycled or not be used again in place around 10-20\% trash to the landfill. In this phase it then process of plutonium or burning final trash can be done by using incinerator.

During the program trash bank it has been much benefit can be felt people living in urban has trash bank, namely:

a) The trash bank benefit to the environment is positive make the environment be cleaner and most perceived by community reduced the garbage around the neighborhood until now become a less attractive around.

b) After the introduction of the banking program, there was a litlle increase of people income in every hometown. It is obtainable from the answers of informant who said the financial condition of those little increased since the banking program. Although a period of time to get the money was about 1-3 months, but the public was 
very results to daily needs, education, to improve the quality of life.

c) After the program trash bank it goes, there so corpulent advantages people save trash. The savings trash, the community also make money. On the income of trash bank, the community to be easier to fund education. In average, families have children were still in school age.With the introduction of the income from Trash Bank, communities helped in finance children education to get the quality of better education.

d) Based on the informants, many changes that happened to health facilities in every hometown. Because trash bank established, automatically all also received the impact of after the construction of trash bank, including health facilities in every hometown. Beside this, public health is increasing.

e) Trash Bank program increase the social interaction among society. People who active in the program also became active in other socialization program in the hometown.

The obstacles of Trash bank at Medan city also of the management of garbage as manage back trash plastic bottles to be handicrafts .Trash bank has constraint at a unit of pounds trash, Trash Bank must compete with mobile craftsmen flea thrift. Because the flea it would pay more than a specified price Trash Bank, suppose for a newspaper the flea put a price Rp. 1.200 while Trash Bank costs Rp. 1.080. The inadequate build the rubbish also difficult to grow.

\section{CONCLUSIONS}

Based on this study some of the things that can be summed up, namely:

1. Problems in community-based waste management in the field of the authority to institution is the current handed over to hometowns. The authority said that they lack of capability to manages the continuity of this program.

2. During the program trash bank it has been much benefit can be felt people living in urban has trash bank.
3. Trash Bank is one alternative to invite people concerned with trash, that the concept may be developed in other area.

\section{REFERENCES}

Ahn, J \& Suzuki, A. (1989). Joint International Waste Management Conference. Journal of Nuclear Science and Technology. 27 (1): 89-94.

Ankesa, H.,Amanah, S., Asngari, P.S. (2016). Kelompok Perempuan Peduli Lingkungan dalam Penanganan Sampah di Sub DAS Cikapundung, Provinsi Jawa Barat. Jurnal Penyuluhan, September 12 (2): 105113.

Berampu, A.C \& Agusta, I. (2015). Manfaat Partisipasi Masyarakat dalam Program Pengelolaan Sampah, Jurnal Penyuluhan. September. 11. (2): 116128.

Bappenas. (2003). Infrastruktur Indonesia; sebelum, sesudah dan pasca krisis. Kementerian Negara Perencanaan Pembangunan Nasional/Badan.

Damanhuri, Ernidan Tri Padmi. (2010). Diktat Kuliah Pengelolaan Sampah, Institut Teknologi Bandung. Bandung.

Wiwaha, A.A., et.al. (2016). Perencanaan Partisipatif Jalur Evakuasi dan Titik Kumpul Desa Ngargomulyo dalam Upaya Pengurangan Resiko Bencana Gunungapi Merapi, Jurnal Perencanaan Wilayah dan Kota. 27 (1): 34-48. 